\title{
Sustainable Solutions to 'Complex Problem-Solving' \\ A Key to Effective Community and Industry Engagement and Partnerships by University Researchers
}

\author{
Submitted: 5 March 2014 \\ Accepted: 7 May 2014 \\ Cameron Richards', Neil Tanquilut ${ }^{2}$ \\ ${ }^{1}$ SUSTiP Research Group, Universiti Teknologi Malaysia \\ cameronkrichards@gmail.com \\ ${ }^{2}$ Pampanga Agricultural College, Philippines
}

\begin{abstract}
Community and industry engagement by universities and academics are sometimes prone to accusations of exclusive or academic 'talk-fests' which can reinforce rather than resolve the 'bridgeable disconnect' between the general community and particular organizations with vested interests (Grayson, 2010). Concrete modes and strategies of 'linking knowledge to action' are needed to build upon the participatory exchange or mediation of stakeholder perspectives and interests. This paper reports on the exploration, development and application of the kind of convergent and also interdisciplinary approach to development studies which might: (a) better link theory and practice as a basis for the elusive goal of strategic 'sustainability', and (b) also encourage and optimize authentic, collaborative, and complex modes of problem-solving as a key to community and industry engagement by academic institutions and researchers. It will do so in relation to some practical case studies in such partnerships.
\end{abstract}

Keywords: collaborative research and development; community-industry-university partnerships; complex problem-solving; interdisciplinary methodologies; sustainability

\section{Introduction}

Community and industry engagement by higher education organizations and academics are sometimes prone to accusations of being 'talk-fests' which can reinforce rather than resolve the 'bridgeable disconnect' between the general community and particular organizations with vested interests [Grayson, 2010].

The reason why innovation has not been effective is obvious to many ... there is a serious gap between the market and the R\&D community...industry players have yet to be convinced that investing some of their earnings in R\&D will help their business. The end result is that institutions do not link, scientists do not partner industry, and industry does not engage academics [Sulaiman, 2010].

In a complex and fast-changing world academic institutions and researchers need to do more to collaboratively engage the wider community and also related industry contexts which increasingly inform the interplay of public governance and markets at local as well as global levels. As Grayson suggests, the central challenge of overcoming what he identifies as the 'bridgeable disconnect' lies in less talk and more action - also, in less specialist theory and more interdisciplinary policy relevance. This is to the extent that policy studies are most appropriately understood as existing knowledge linked to future action and implementation. Such an approach also requires a better and more relevant alignment of the academic knowledge-building process and the complex as well as concrete challenges and dilemmas confronting diverse communities around the world. For, as Sulaiman conversely suggests, academics will need to do a better job also of convincing industries more specifically - and markets more generally - that the disciplined neutrality and methods of academia can still be a crucial key to achieving the innovation targets and imperatives which are increasingly national targets within the global context of an emerging and interdependent knowledge economy.

The opportunity to assist with establishing a new university faculty and associated research group ${ }^{1}$ focus on 'science, technology and innovation policy' studies provided the foundation for (a) also exploring sustainability as well as innovation studies well-suited for (b) re-visiting the challenge of academic collaborative partnerships with industries as well as wider social contexts of community. On this basis an emerging framework of 'collaborative complex problem-solving' was conceived. It has already been used in a number of related studies which propose and apply a more reciprocal and interactive model of university-industry-community partnerships (e.g. Richards, 2012a, 2012b, 2012c; Richards \& Padfield, in press). Such a foundation needed to go beyond the typically either/or of top-down vs. ad hoc approaches

\footnotetext{
${ }^{1}$ UTM's SUSTiP Research group (Sustainable STI policy solutions for industry, government and society)
} 
of typically dominant public policy models (e.g. Parsons, 2002; Rutland \& Aylett, 2008; Mowery, Nelson \& Martin, 2009). In other words as we explore in this paper, this required a more convergent rather than divergent approach to what the innovation theory/policy paradigm calls the 'quadruple helix' but we prefer to designate as the four 'macro policy stakeholders' of industry-government-community and 'research and development (Richards, 2012). Likewise an integrated and interdisciplinary framework provides a basis for applying the traditional academic importance of critical rigor in knowledge-building inquiry and problemsolving to the myriad related economic and environmental sustainability challenges in need of innovative and interdisciplinary as well as innovative new solutions - that is, the ever-complicated and difficult challenges facing nature and society in the face of the alternate but inevitably related threats of the global financial crisis and the global 'ecological' (or 'limits to growth') crisis (Gallagher, 2005; Lomberg, 2007; Rist, 2008; Ramo, 2010; Gilding, 2011).

This paper explores how significant refinements to an integrated 'sustainable science, technology and innovation policy-related framework' was in part inspired by a visit to and initial collaboration with prospective doctoral students from a Philippines Agricultural College (PAC) located north of Manila in Central Luzon ${ }^{2}$. As indicated below, many of the PAC academic staff were interested in collaborative projects with local communities and industries which encouraged optimal human as well as natural resource 'policy' solutions involving projected collaborative partnerships. In this way the paper is organized in three sections. The first part discusses the kind of convergent, applied, and interdisciplinary as well as collaborative methodology needed for more constructive university-community and university-industry partnerships. This collaborative or dialogical methodology is provisionally explored and developed in relation to two interesting and exemplary proposed case studies outlined in the second and third parts of the paper.

The first case study explores the emergence or development of a sustainable design concept for PAC to add support to and even take the lead in a community-based 'Save Mt. Arayat' campaign. This is a proposed academic-community collaboration to reverse the degradation of not only the local environment for various stakeholders (local community, farmers, businesses, etc.) but also the associated threat to a local Filipino community and their livelihoods. The second study explores the design of a proposed PAC initiative to work with the Philippines Racing Industry to provide an immediate response yet also sustainable solution to emerging reports of an urgent and mysterious problem of horse infertility which potentially threatens the viability of an important industry. The study looks at how the need for an urgent response will also require the kind of integrated yet also concretely practical 'systems' thinking and methodology of 'wicked (i.e. complex) problem-solving' (e.g. Kolko, 2012) which converges both an optimization of scientific research support but also the related application of both an effective knowledge management principles and 'stakeholder' perspectives.

\section{University-Industry-Community Partnerships as a Key Focus of a Paradigm Shift In Relations between the Four Macro-Stakeholders of Sustainable Policy}

The central dilemma of policy-building for local and national governments around the world derive from the global imperative of the modern age to marketise, to privatize, and to develop in the name of 'progress' (or 'growth') every last cultural as well as physical domain of the 'public good' and community 'commons'. We have discussed elsewhere this imperative in relation to the industrialization of even the public good domains of water and education (Richards \& Padfield, in press; Richards, 2012d). Rivkin $(1998 ; 2011)$ has usefully described the nationalist as well technological imperative of 'modern progress' to enclose the global commons (including the resources of water, air, and land) beyond feudal as well as traditional models of the public good (Cf. also Kopelman, 2009). As Cardin (1968) influentially pointed out, the 'tragedy of the commons' - how the depletion of shared resources in terms of immediate or short-term self-interest is an imperative perpetually in conflict with common or social interests - has gone from a local to a global challenge in the historical transition from traditional societies to the modern age. As he points out, such a transition has also typically involved an arbitrary separation between or related conflict of technical solutions and sustainable social values. This compares with the influential if ostensibly contradictory notion of sustainable development outlined by the Buntland Commission (1987) as 'development that meets the needs of the present without compromising the ability of future generations to meet their needs'.

Thus, as Table 1 depicts, a related distinction can be made between a progressive model of conflicting or competing stakeholders and a sustainability model of stakeholder convergence at both the macro and micro levels. Abrell (2009) points out how a common human heritage also includes traditional and indigenous as well as modern knowledge systems from every local and diverse cultural context in the international context. Whether linked to traditional social values or modern ideologies of progress and positivism, science and technology are inevitably critical to the development of knowledge to address or solve various human challenges or problems (Spence, 2011). As Nisbert (2009) suggests, modern notions of organic growth and mechanical interplay of parts in any whole system derive from and represent a reversal of traditional notions of internal emergence balanced rather by external challenges of dynamic equilibrium or homeostasis. Likewise a complex problem-solving approach to systemic challenges of

\footnotetext{
2 Pampanga Agricultural College is one of the Philippines' top public agricultural colleges with an increasingly strong research focus. It is presently applying for upgrading to university status.
} 
environmental adaptation also reflects a balanced framework for the optimization of natural as well as human resources (Richards, in press). In this way also, an interdisciplinary approach to the various and increasing 'wicked problems' which confront governments, businesses, and communities in interdependent ways inevitably integrates different aspects of interdisciplinary as well as specialized knowledge. In contrast to rational vs. ad hoc notions of 'progress', a sustainability framework and paradigm reflects the emergence of an ecology or ecosystem of different kinds of human knowledge based on a dialogical convergence of stakeholders.

Table 1. From 'Progress' to 'Sustainability': The Key to Framework Convergence?

\begin{tabular}{|c|c|c|c|}
\hline \multirow{2}{*}{\multicolumn{2}{|c|}{$\begin{array}{l}\text { Progress (competition, profits, etc.) } \\
\text { 'Conflicting priorities between government, commercial and civil } \\
\text { society sectors'? }\end{array}$}} & \multirow{2}{*}{\multicolumn{2}{|c|}{$\begin{array}{l}\text { Sustainability ( consensus, quality, etc.) } \\
\text { 'development that meets the needs of the present without compromising } \\
\text { the ability of future generations to meet their needs' [UN 1987) }\end{array}$}} \\
\hline & & & \\
\hline$\%$ & $\begin{array}{l}\text { Human development as elitist and rational progress for its own } \\
\text { sake }\end{array}$ & & $\begin{array}{l}\text { Human development in balance with the capacity of nature to } \\
\text { renew or sustain itself }\end{array}$ \\
\hline$*$ & $\begin{array}{l}\text { Wasteful, profit-driven and top-down rationale for use of } \\
\text { natural and also human resources }\end{array}$ & & $\begin{array}{l}\text { Responsible satisfaction of needs in terms of a basic human quality } \\
\text { of life }\end{array}$ \\
\hline$\nLeftarrow$ & $\begin{array}{l}\text { Careless indifference to the effects of pollution and the loss of } \\
\text { biodiversity }\end{array}$ & $\%$ & $\begin{array}{l}\text { Growing concern about the need to restore/renew the biodiversity } \\
\text { of the natural environment }\end{array}$ \\
\hline$\nLeftarrow$ & An economy based on endless growth and consumption & $\%$ & $\begin{array}{l}\text { Economy based on sustainable development to reconcile present } \\
\text { and future human needs }\end{array}$ \\
\hline 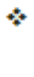 & $\begin{array}{l}\text { Complicit role of science and technology to dissect and control } \\
\text { nature as basis of knowledge progress }\end{array}$ & & $\begin{array}{l}\text { The role of (green) science and technology for ecological } \\
\text { convergence of society and nature }\end{array}$ \\
\hline$\%$ & $\begin{array}{l}\text { Nature riewed as an unlimited resource to be exploited for profit } \\
\text { in competition with others }\end{array}$ & 4 & $\begin{array}{l}\text { Nature as a global commons to be shared more equitably between } \\
\text { all peoples }\end{array}$ \\
\hline$\%$ & $\begin{array}{l}\text { Humanity stuck in the privileged agendas and exclusive } \\
\text { ideologies of the past }\end{array}$ & & $\begin{array}{l}\text { The future an 'emergent' focus for reconciling cultural, social, and } \\
\text { economic differences }\end{array}$ \\
\hline$*$ & $\begin{array}{l}\text { Conflicting priorities between government, commercial and civil } \\
\text { society sectors }\end{array}$ & 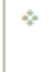 & $\begin{array}{l}\text { The convergent interests of government, commercial and civil } \\
\text { society sectors }\end{array}$ \\
\hline
\end{tabular}

In innovation theory the 'quadruple helix' model refers to how an integrated interplay of business/industry, community and 'academia' as well as government provides a key to the most effective strategizing and decision-making to produce innovative solutions to diverse challenges (e.g. Carayannis \& Campbell, 2012). We think it is more accurate to refer to these actors as the four macro stakeholders of sustainable policy solutions based also on interdisciplinary foundations. As epitomized by the concept of 'green technology' (e.g. Friedman, 2009), there is growing recognition that - in the face of increasing and globalised governmental policy paralysis about a range of complex problems linked to both the global financial crisis and 'global warming' - leadership for sustainable as well as innovative policy solutions will also need to involve specific industry contexts and the private or commercial sector more widely. Thus in the next section we outline a model of how academic or ' $R$ \& $D$ ' knowledge-building can be applied to contexts of industry-based problem-solving also inevitably needing to reconcile social, economic and natural environments. The key to this, we suggest, is the academic application of a systems model of complex problem-solving which applies conventional academic values of discipline, neutrality and rigorous inquiry to the policy challenges of linking diverse stakeholders and domains of knowledge in applied or practical contexts. This should also reflect an interdependent as well as independent view of related realms of knowledge often seen as distinct or separate: technical and management domains, natural and human sciences, mechanical vs. information/communication/virtual technologies, and so on.

\section{1. 'Policy Challenges' Research}

Policy studies and research any kind of involving complex or at least challenging problem-solving tends to be defined by an 'either-or' delineation between rational or top-down and an ad hoc (i.e. 'muddling') rather than emergent bottom-up approaches to policy related inquiry (e.g. Parsons, 2002). Academic approaches likewise tend to typically emphasize a related quantitative vs. qualitative opposition. On one hand this typically involves the descriptive accumulation of data in specialist areas thus reflecting a silo approach to knowledge. On the other hand, various models of action or participatory research are often criticized for failing to link 'talk' or stakeholder discussion to concrete strategies of action and change (e.g. Frideres, 1992 ). We have elsewhere pointed out how the rational/top-down vs. ad-hoc delineation tends to not only encourage policy 'flip-flopping' but also eventual policy paralysis as a vicious circle of inbuilt sustainability failure (Richards, 2012a). An emergent balancing of macro directions and micro details constitutes a rather outcomes-based approach to policy-building studies or process involving the opening up and negotiation of a 'policy space' (Gallagher, 2005). This helps to avoid the problem of a merely selective and counter-productive mode of evidence-based policy-making as retrospective justification for arbitrary or ad hoc decision-making and planning.

The insights of Framing Theory support the view that a sustainability approach should also involve the relevant, appropriate and strategic re-framing of 'intractable policy problems or challenges' (Schon \& Rein, 1994). As we demonstrate below, this might involve breaking complex problems down into key supporting challenges and then an integrated approach to systemic change and transformation. We have 
elsewhere discussed two related methodologies which also dovetail with a systems approach to complex problem-solving (Richards, 2012b). One is emerging design-based paradigm which has application to both technical and knowledge innovation (e.g. Reeves, 2006)). Convergent design solutions and problem reframing are both approaches which provide solid support for an interdisciplinary approach to the research process especially applicable to university collaborations with community and industry. As the US National Academies' Committee on Science, Engineering, and Public Policy (COSEPUP) (2004, p.26) has influentially defined it:

Interdisciplinary research (IDR) is a mode of research by teams or individuals that integrates information, data, techniques, tools, perspectives, concepts, and/or theories from two or more disciplines or bodies of specialized knowledge to advance fundamental understanding or to solve problems whose solutions are beyond the scope of a single discipline or field of research practice.

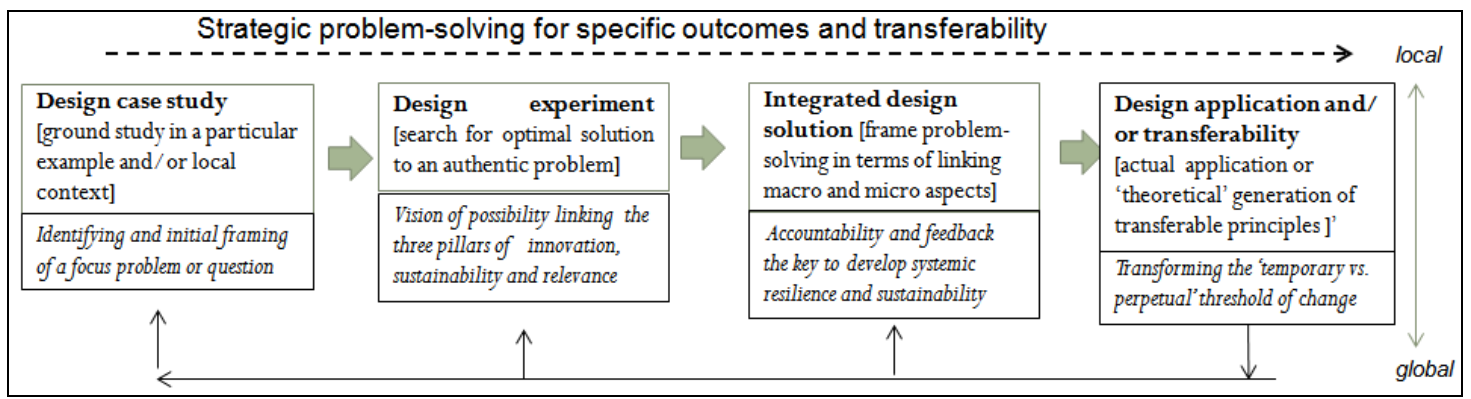

Figure 1. An integrated representation of the design research framework

(Source: Adapted from Richards 2012b)

Self-organizing complex systems typically involve both internal and external factors in any resilient adaptation to complex and changing environments (Heylighen, 2001; Mitleton-Kelly, 2003). Easterly (2006) has usefully pointed out how, like other human knowledge systems, policy systems require both internally consistent accountability and externally-open feedback mechanisms for sustainability - that is, also for independent and integrated rather than co-dependent or parasitic resilience. Linked to an interdisciplinary framework of related or linked knowledge domains this reflects how communication and knowledge management frameworks provide the 'internal' key to the optimization of human resources just as the sustainable alignment of economic and natural environmental adaptation needs like provides a basis for focused science and technology innovations. In this way policy studies provide a foundation for universities to take more direct and pivotal role in the macro stakeholder structure of various kinds of complex problems which inevitably link the domains of society and nature as well as technology and management. As Figure 1 indicates, innovative policy solutions to authentic problems might always be explored and refined as either formal or informal 'design experiments' which anticipate all manner of potential future obstacles.

\section{Saving Mt Arayat: University Research for Community Development Based Also Around Environmental Sustainability}

In essence the 'Save Mt. Arayat' idea and evolving campaign addresses how environmental degradation is often linked to the possible future demise of a predominantly rural community. Mt. Arayat is a rural area north of Manila where the community and ultimately local education institutions as well as businesses are mainly dependent on farming. However the long dependence on artificial fertilizers as well as pesticides have linked with other factors such as deforestation, 'over-farming', and urban creep to see a deterioration in the quality of the land and loss of biodiversity. Such developments have undermined not only the local quality of life but the potential of the area to be a recreational, tourism, and 'green' centre in Central Luzon. With the effects of these developments not only impacting on the community but also education institutions, mutual self-interest was the natural rationale for academics as well as students from the Pampanga Agricultural College (also incorporating a teacher education and other faculties supporting a current application for upgrading to university status) to become interested in more directly contributing to a community-based awareness campaign with also an online presence (http://www.facebook.com/pages/Save-Mt-Arayat/141106386032421 ?ref=ts\&fref=ts).

In a discussion session with colleagues from the PAC Institute of Arts and Sciences, mention was made of their efforts to develop the Save Mt. Arayat concept into a formal proposal to get project funding to support planned initiatives. This application had apparently failed in part because of a perceived lack of an integrated approach. Our discussions about how this aspect might be improved naturally revolved around how a disciplinary divergence of the faculty might be re-framed in relation to convergent overall purposes in other words, how might the various knowledge domains of the human and social sciences complement those of the natural sciences?

It just so happened that at the time of our visit a retired former academic at the college gave a talk on the benefits of using 'green manure' (i.e. cover and mixed crop) techniques from the past to assist in revitalizing the soil and improving biodiversity as well as lessen dependence on artificial fertilizers and 
chemical pesticides. Thus discussion focused on how the agricultural scientists in the institute and across the college more widely might undertake (a) related research projects of biotechnology innovation and sustainability focused on the natural environment, plants and wildlife whilst (b) the social scientists and humanists might focus rather on engaging public awareness and encouraging business interests as well as social support - including relevant disciplines such as law, psychology, and education. Some initial studies had already been undertaken but the suggested integrated framework encouraged motivation as well as collaboration. There was further talk about how a virtuous circle (to replace the perceived downward spiral) might be promoted where community volunteers would be encouraged to participate in tree-planting and other programs, and also the business community might be likewise encouraged to sponsor related activities, if they could see not only action but a usefully integrated plan.

\begin{tabular}{|c|c|}
\hline $\begin{array}{l}\text { What is the req } \\
\text { and strategic pl } \\
\text { theme of 'Savin } \\
\text { sustainability of }\end{array}$ & $\begin{array}{l}\text { red strategy or formula to link scientific research } \\
\text { nning in order to organize a project around the } \\
\text { Mt. Arayat (saving the economic and social } \\
\text { a Filippino local community) }\end{array}$ \\
\hline & $\begin{array}{l}\text { What are the main principles or elements of the most sustainable } \\
\text { rmula or plan to save Mt. Arayat? [What would be the main obstacles } \\
\text { coming up with a workable tormula or strategy supported by all } \\
\text { takeholders?] }\end{array}$ \\
\hline & $\begin{array}{l}\text { 2. How can the situation be addressed and remedied in terms of a } \\
\text { convergence of (a) new scientific methods and knowledge for } \\
\text { sustainable farming and use of natural resources in area?, and (b) } \\
\text { new management methods and also community involvement? }\end{array}$ \\
\hline & $\begin{array}{l}\text { 1. What are the kinds of damage being caused to Mt. Arayat } \\
\text { (loss of biodiversity, deforestation, etc.) and how is this being } \\
\text { caused by existing human influences and practices? }\end{array}$ \\
\hline ationale: There are gro & $\begin{array}{l}\text { ing concerns about economic and social sustainability of the Mt. Aravat area. } \\
\text { ociated problems of decreasing biodiversity, deforestation and lana/forest } \\
\text { early then there is need for an integrated approach to both getting cooperation } \\
\text { ut also getting agreement and action on the most productive strategy for the } \\
\text { ye in the area in the future. The proposed 'Save Mt Arvat' initiative from PAC } \\
\text { ected by the problem) also needs to spread awareness to get support of the } \\
m \text { the government and private sector. Therefore this project needs to establish } \\
\text { tific research and strategic planning are the keys to 'Saving Mt. Aravat'. }\end{array}$ \\
\hline
\end{tabular}

Figure 2. Framing an Integrated Approach To the 'Save Mt. Arayat' Inquiry

Our collaborative discussions about devising a more integrated framework and project design came up with the model outlined in Figure 2. As outlined, the rationale behind this was a projected strategy for the PAC Institute of Arts and Science to take the lead in engaging the local community in terms of research and inquiry linked to an authentic context as an academic-community collaboration. In this way the figure emphases how the local PAC expertise in 'scientific research' (also including social scientific as well as agricultural science studies) might be integrated around a related 'strategic planning' emphasis. This also corresponds to a related link between applied and tacit modes of a knowledge management perspective. The key to behavior change and the optimization of natural as well as human resources in this case also clearly depends on engaging and linking in the long term diverse stakeholder interests and also capacities. It helps to view this also within a 'macro stakeholder' context (see Figure 3 below).

\begin{tabular}{|c|c|c|c|}
\hline \multicolumn{2}{|c|}{$\begin{array}{l}\text { UNIVERSITIES } \\
\text { As 'ivory towers' } \\
\uparrow\end{array}$} & \multicolumn{2}{|c|}{$\begin{array}{l}\text { UNIVERSITIES } \\
\text { As neutral facilitators } \\
\text { /independent 'think-tanks' } \\
\text { (R \& D/ Education) }\end{array}$} \\
\hline $\begin{array}{l}\text { GOVT./AGENCIES } \\
\text { As 'top-down'/ } \\
\text { bureaucratic control }\end{array}$ & $\begin{array}{l}\text { COMMERCIAL/ } \\
\text { INDUSTRY SECTOR as } \\
\text { ruthlessly profit-driven } \\
\text { and exploiter of natural/ } \\
\text { common resources }\end{array}$ & $\begin{array}{l}\text { GOVT./AGENCIES } \\
\text { Representing } \\
\text { society's sustainable } \\
\text { interests }\end{array}$ & $\begin{array}{l}\text { COMMERCIAL/ } \\
\text { INDUSTRY } \\
\text { SECTOR as focus } \\
\text { of innovation and } \\
\text { exchange }\end{array}$ \\
\hline \multicolumn{2}{|c|}{$\begin{array}{l}\text { COMMUNITY/CIVIL SOCIETY } \\
\text { as exclusive (us vs. them), } \\
\text { consumer-driven and careless }\end{array}$} & \multicolumn{2}{|c|}{$\begin{array}{l}\text { COMMUNITY/CIVIL SOCIETY as } \\
\text { inclusive, caring, and equitable } \\
\text { sharing of natural/cultural resources }\end{array}$} \\
\hline
\end{tabular}

Figure 3. Towards a positive scenario of macro stakeholder convergence 
The negative view above of macro stakeholder relations does not just reflect linked 'profits, progress, and short-term' perspectives but also divergent us vs. them modes of communication and either/or modes of thinking. The gesture of PAC to engage its local community was also an invitation to different groups within that community to also work together in a mutually supportive as well as 'win-win' fashion. Thus the PAC direct involvement in the Save Mt. Arayat campaign epitomizes a related transition from a conflicting and self-contained view to rather take a convergent and interdependent view of the macro stakeholder dynamic. The primary emphasis focused on the vertical axis of academic-community collaboration. However as indicated above there was also related efforts to engage local businesses and government (or non-government) agencies active in the local area.

\section{Racing against Time: An Authentic Industry Challenge as A Focus For Developing An Integrated Framework For Optimal And Sustainable Solutions.}

In the Philippines the local Racing Industry plays a significant role in society with a range of stakeholders beyond the owners, trainers and jockeys who participate in the racing of thoroughbred horses. As well as the sporting interest it attracts, Philippines racing also generate significant revenues for the Government. However recently there has been concern that a serious deterioration in foaling rates with no obvious cause or explanation potentially threatens the future viability of this industry. Our interest in framing an 'integrated, optimal and sustainable' possible industry solution derives from discussions about a proposed doctorate with a local colleague from the PAC Institute of Veterinary Medicine. He was considering linking this to an emerging industry challenge that he had been made aware. Thus we discussed his planned $\mathrm{PhD}$ as academic-industry collaboration and explored possible options for a relevant research design and methodology which might suitably converge useful industry outcomes and academically substantial inquiry.

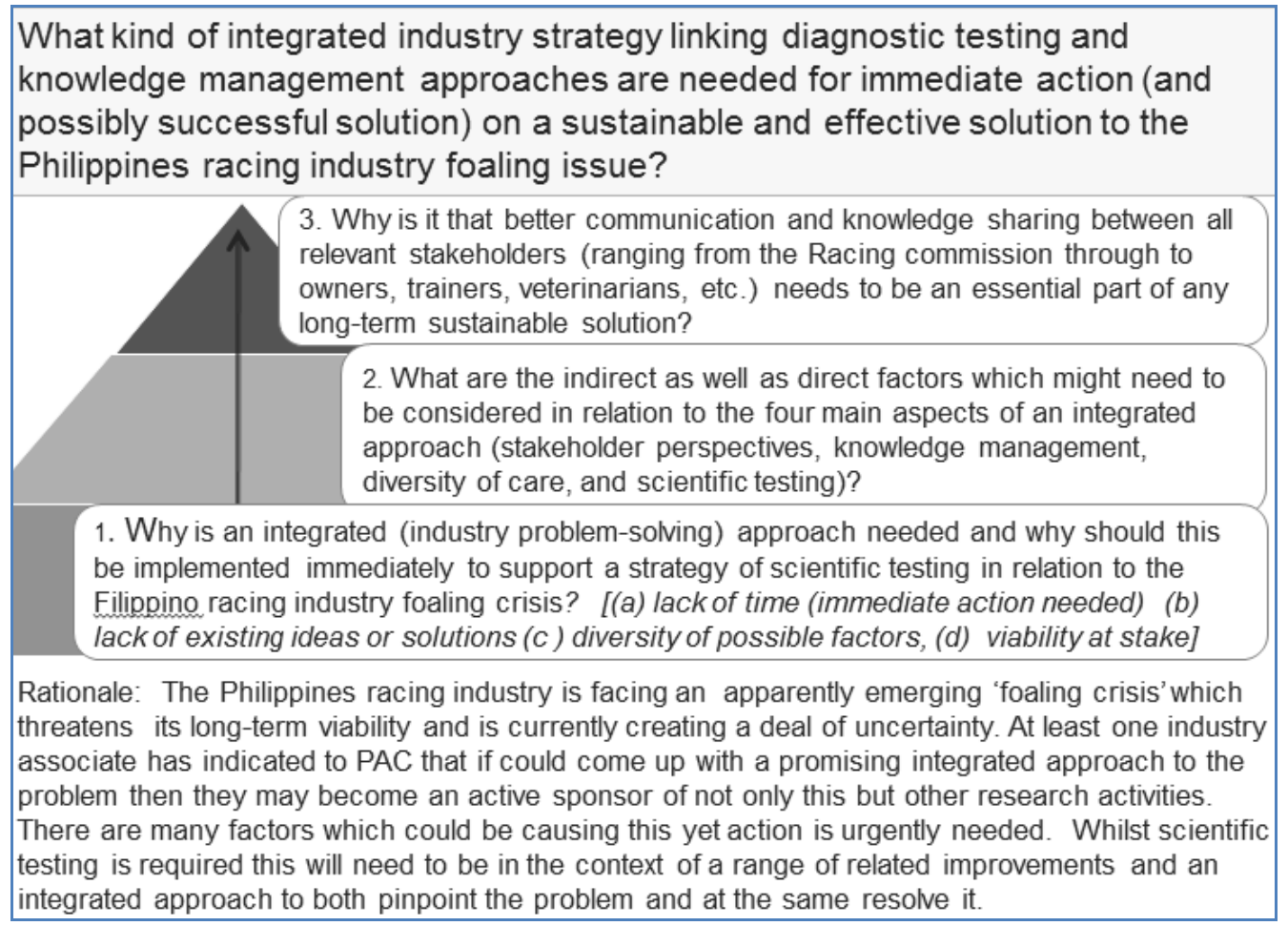

Figure 4. Framing an integrated approach to the 'racing against time' inquiry

As well as a growing sense of urgency about this problem there was confusion and consternation that there was no obvious cause along the lines of the 1997 equine influenza outbreak. This also presented a dilemma typical of a complex systems model of problem-solving. If it was just a matter of some kind of treatable infection then it would be simple enough to find a solution. Thoroughbred horses are a sensitive breed prone to fertility problems from a range of causes ranging from genetic issues of inbreeding through to aspects of management, shelter and nutrition. This is especially so in the Philippines where we discovered that the cost of importing overseas stallions (the normal remedy of artificial insemination is not allowed in thoroughbred racing) meant a high inbreeding level in a breed which by definition is relatively 'inbred' already. So was it a matter of some specific causes which might be pinpointed and addressed in reasonable time or was it a complex combination of factors that had somehow converged in more deep-set problems? A narrow scientific research inquiry might focus on longitudinal studies of possible genetic conditions or disorders as the cause. Yet there may be other significant contributing factors that might also take years to properly diagnose the condition. But it seemed possible or 
even likely that the Philippines Racing Industry might not have much time to address the problem without major consequence which could include the complete collapse of the industry. Something needed to be done but what? The challenge of coming up with an integrated problem-solving design to optimise the chances of diagnosis and recovery was the identified task design.

The systems approach to problem-solving intuitively practiced by good doctors, mechanics and thinkers tends to link two related steps. On one hand there may be established repertoires for pinpointing specific causes which can be easily remedied thus assuming or demonstrating that the general health or quality of the system is in order. If not such surface problem-solving solutions are applicable then it becomes a case of trying to optimize the system to restore reasonable efficiency or health. In the case of coming up with a strategy to potentially assist the Philippine racing industry we needed to identify and simultaneously cover or address a range of factors in terms of ongoing controls which would both pinpoint and optimize a range of possible direct and indirect causal factors at the same time. Figure 4 frames an integrated approach to policy-related knowledge building relevant to an optimal response to this challenge.

As suggested above our Philippine colleague was a veterinary scientist with enough experience also of horses to be aware that there might be an interplay of causal factors beyond or linked to either some virus or emergent genetic issue. He informed us nutrition, shelter and other aspects of care were not always as much a priority in the Philippines as in some overseas racing industries. It would be difficult to not only integrate new breeding and training mechanisms but also to get better knowledge and communication coordination between owners, trainers and various assistants. He pointed out that female horses (mares) in the Philippines tend to be raced more often and to an older age before they retired to foaling than overseas. In this way we began to sketch the outlines of 'knowledge management' strategies which might be used to provide optimal support for some targeted diagnostic testing and control groups as part of a wider integrated strategy of response. This was linked to the systems model of four critical factors developed below in Table 2 as part of an industry-based problem-solving model.

Table 2. A systems model of the four critical factors in industry-based problem-solving

\begin{tabular}{|c|c|c|c|}
\hline $\begin{array}{l}\text { Stakeholder consensus / } \\
\text { communication channels }\end{array}$ & $\begin{array}{l}\text { Knowledge management } \\
\text { (human resource optimisation) }\end{array}$ & $\begin{array}{l}\text { Science and technology } \\
\text { innovations (process and } \\
\text { products of human knowledge) }\end{array}$ & $\begin{array}{l}\text { Adaptation to changing } \\
\text { economic vs. natural } \\
\text { environments }\end{array}$ \\
\hline $\begin{array}{l}\text { Develop sufficient convergence of } \\
\text { perspectives, interests \& general } \\
\text { consensus in order to provide a } \\
\text { foundation for a common } \\
\text { commitment and purpose to an } \\
\text { achievable outcome. }\end{array}$ & $\begin{array}{l}\text { Encouraging, supporting and } \\
\text { harnessing tacit knowledge of } \\
\text { sector/industry-focused } \\
\text { stakeholders towards improved } \\
\text { performance for overall or } \\
\text { 'systemic' change and improvement }\end{array}$ & $\begin{array}{l}\text { To design and develop new } \\
\text { solutions or adapt existing } \\
\text { knowledge to new challenges and } \\
\text { different contexts (applications, } \\
\text { processes or products re: specific } \\
\text { physical/economicenvironments) }\end{array}$ & $\begin{array}{l}\text { What changes or crises in society and } \\
\text { nature represent an obstacles or } \\
\text { challenge to be addressed to } \\
\text { maintain or restore sustainability, } \\
\text { viability and equitable sharing of } \\
\text { resources }\end{array}$ \\
\hline $\begin{array}{l}\text { MACRO - in relation to } \\
\text { distinct govt., commercial, } \\
\text { civil society and academic } \\
\text { perspectives/ partnerships }\end{array}$ & $\begin{array}{l}\text { Linking 'small' /related } \\
\text { problems and solutions to } \\
\text { addressing big/central problems } \\
\text { - and also developing solutions] }\end{array}$ & $\begin{array}{l}\text { Science as accumulated vs. } \\
\text { applied social knowledge }\end{array}$ & $\begin{array}{l}\text { Natural environment } \\
\text { (dynamic homeostasis) }\end{array}$ \\
\hline $\begin{array}{l}\text { MICRO - internal to } \\
\text { particular organization, } \\
\text { industry, nation or even } \\
\text { global level organization }\end{array}$ & $\begin{array}{l}\text { Leadership/management } \\
\text { develop a repertoire of micro } \\
\text { interventions to tackle } \\
\text { anticipated obstacles }\end{array}$ & $\begin{array}{l}\text { Technology as extension of } \\
\text { mind-body through tools, } \\
\text { machines, and cultural-virtual } \\
\text { networks }\end{array}$ & $\begin{array}{l}\text { Vs. Changing social, economic } \\
\text { and cultural contexts } \\
\text { (growth) }\end{array}$ \\
\hline Integrity, communication & $\begin{array}{l}\text { Strategic planning/ } \\
\text { collaboration }\end{array}$ & Experimentation & Observation \\
\hline $\begin{array}{l}\text { Consensus-building } \\
\text { (convergences despite us } \\
\text { vs. them divergences) }\end{array}$ & $\begin{array}{l}\text { Capacity-building (ecological } \\
\text { ys hierarchical optimization } \\
\text { of human resources) }\end{array}$ & $\begin{array}{l}\text { Applied knowledge-building } \\
\text { - from data/info to } \\
\text { experience/understanding }\end{array}$ & $\begin{array}{l}\text { Sustainability-building } \\
\text { ('ecological' optimization of } \\
\text { natural resources) }\end{array}$ \\
\hline
\end{tabular}

Source: Adapted from Richards \& Padfield (in press)

The aspects of knowledge management which related to better and integrated information systems to do with the breeding, training and general care of horses needed to be established in terms of also better communication challenges between the different particular stakeholders and their various perspectives. This applied from the more micro level of direct horse management through to the macro directions and agreements at the industry level. Likewise any diagnostic testing needed to be done in light of or with reference to a careful monitoring and consideration of both environmental factors of nutrition, shelter and general care on one hand, and on the other aspects to do with breeding, training and related issues to do with different practices. All of this needed to be triangulate carefully in relation to any diagnostic testing for genetic or more direct causal factors.

Figure 6 thus also provides a useful overview of an interdisciplinary framework for possible academic-industry collaborative inquiry and partnerships to address complex problem-solving challenges. The internal axis proceeds on the practical basis of recognizing how effective consensus and dialogue are the most effective key to optimizing the human resource and knowledge management factors. Conversely any 'science and technology' innovations to optimise natural resources need to proceed in relation to the applied as well as observational foundation of changing economic vs. natural environments. 


\section{Conclusion}

This paper has reported on: (a) how a trip to the Philippines led to some collaborative inquiry approaches to a range of community and industry-focused case studies, and (b) how also this assisted with designing and developing some generic models of complex collaborative problem-solving in terms of deep or long-term sustainability and not just quick policy 'fixes'. We have outlined how the rationale of the Save Mt. Arayat campaign helped us to think more clearly about how a convergent and sustainable rather than divergent and ultimately counter-productive 'profits and progress' interplay between the four macroproblem-solvers can be encouraged and achieved. Likewise the Racing against time' design experiment helped us to better understand the interdependent systems framework of any complex problem-solving. This also needs to be based on stakeholder collaboration based on the interdisciplinary foundations and implications of four distinct but related critical factors (stakeholder communication, knowledge management, science and technology innovations, and economic vs. natural environments). In this way we have outlined a more productive model for both academic-community and academic-industry collaborative research inquiry and partnerships which is not only authentic but a solid foundation for encouraging innovation as well as sustainability in the knowledge building process for planning, decisionmaking and policy studies more generally.

\section{Acknowledgements}

The authors would like to take the opportunity to thank UTM for funding this research under the project 'Framing and harnessing the new marriage between policy studies and applied science and technology research' (Vote No Q.Ki130000.7139.021146). We would also especially acknowledge the assistance and support of Dr. Honorio Soriano, President of PAC, and Dr. Jacqueline Viste-Bagunu, Dean of the PAC Institute of Arts and Sciences.

\section{References}

Abrell, $E$ et al 2009. Imagining a traditional knowledge commons. A community approach to sharing traditional knowledge for non-commercial research. International Development Law Organisation, Viewed Available at www.idlo.int

Carayannis, E \& Campbell, D 2012. Mode 3: Knowledge production in quadruple helix innovation Systems, Springer Briefs in Business, Vol. 7. Viewed at http://link.springer.com/chapter/10.1007/978-1-46142062-0 1

Committee on Facilitating Interdisciplinary Research, National Academy of Sciences, National Academy of Engineering, Institute of Medicine. 2004. Facilitating Interdisciplinary Research. National Academies Press.

Easterly, W 2006. The white man's burden: Why the West's efforts to aid the rest have done so much ill and so little good, Penguin Books.

Frideres, J 1992. Participatory research: An illusionary perspective. in J.Frideres (ed.), $A$ world of communities: Participatory research perspectives. Captus University Publications.

Friedman, T 2009. Hot Flat and Crowded, $2^{\text {nd }}$ edn. Picador Books.

Mowery, R Nelson, R \& Martin, B 2009. Technology policy and global warming: Why new policy models are needed (or why putting new wine in old bottles won't work), National Endowment for Science, Technology and the Arts (NESTA), London

Gallagher, K ed 2005. Putting development first: The importance of policy space, Zed Books.

Grayson, R 2010 Talkfest indicates disconnect between community and peak environment organisations, Pacific Edge Blog, Available at http://pacific-edge.info/climate action conference/

Gilding, P 2011. The great disruption, Bloomsbury Press

Hardin, G 1968. The tragedy of the commons. Science 162 (3859): 1243-1248.

Heylighen F 2001. The science of self-organisation and adaptivity, in L. Kiel, (ed.) Knowledge Management, Organizational Intelligence and Learning, and Complexity, Eolss Publishers, Oxford.

Kolko, J 2012. Wicked problems: Problems worth solving, Austin Center for Design.

Parsons, W 2002. From muddling through to muddling up: Evidenced based policy-making and the modernisation of British Government, Public Policy and Administration 17, 3, 43-60

Kopelman, S 2009. The effect of culture and power on cooperation in commons dilemmas: Implications for global resource management. Organization Behavior and Human Decision Processes, 108, 153163.

Lomborg, B ed 2007. Solutions for the world's biggest problems, Cambridge University Press.

Mitleton-Kelly, E 2003. Complex systems and evolutionary perspectives on organisations, Elsevier.

Nisbert, R 2009 Metaphor and history: The western idea of social development, Transaction.

Ramo, J 2010 The age of the unthinkable, Back Bay Books.

Reeves, T 2006. Design research from the technology perspective. In J. Akker, K. Gravemeijer, S. McKenney, \& N. Nieveen (eds.), Educational design research. London: Routledge, 86-109.

Richards, C 2012a. Sustainable policy making and Implementation: Towards a new paradigm for a changing world, Development Review, Vol. 21, Bangladesh National Academy for Planning and Development. 
Richards, C 2012b. Using a design research approach to investigate the knowledge-building implications of online social networking and other Web 2.0 technologies in higher education contexts, Instructional Technology Research, Design and Development: Lessons from the field, eds. N. Alias \& S. Hashim, IGI Global Press, 117-140.

Richards, C 2012c. Policy studies as framework for the renewed role of ethics in science and technology, Philippiniana Sacra, 46, 140, 409-442.

Richards, C In press. Old wisdom for a new world in crisis?: The enneagrammatic structure of integrated, optimal and sustainable problem-solving, Emergence: Complexity \& Organization

Richards, C \& Padfield, R in press. Water as an exemplary focus of sustainable policy development: A Malaysian case study, International Journal of Environmental Policy and Planning

Rist, G. 2008. The history of development: From western origins to global faith, $3^{\text {rd }}$ edn. Zed Books.

Rifkin, J. 1996. Biosphere politics, Harper.

Rifkin, J. 2011. The third industrial revolution: How lateral power is transforming energy, the economy, and the world, Palgrave Macmillan.

Rutland, T \& Aylett, A 2008. The work of policy: Actor networks, governmentality, and local action on climate change in Portland, Oregan. Environment and Planning: Society \& Space, 28, 627-646.

Schon, D \& Rein, M 1994. Frame reflection: Towards the resolution of intractable policy controversies, Basic Books.

Spence, M 2011. The next convergence: The future of economic growth in a multispeed world, Farrar, Strauss \& Giroux.

Sulaiman, Y. 2010. Unravel the future and strategise the present. New Straits Times, $3^{\text {rd }}$ November. p.21 The Brundtland Commission 1987. Our common future, Oxford University Press. 
Sustainable Solutions to 'Complex Problem-Solving': A Key to Effective Community and Industry...

10 | IJPD Volume 1 No 1 September 2014, 1-10 